\title{
1 Anthropogenic carbon inventory in the Gulf of Cádiz
}

2 Susana Flecha ${ }^{\mathrm{a},{ }^{*}}$, F. F. Pérez ${ }^{\mathrm{b}}$, Gabriel Navarro ${ }^{\mathrm{a}}$, Javier Ruiz ${ }^{\mathrm{a}}$, Irene Olivé ${ }^{\mathrm{c}}$, Susana

3 Rodriguez-Galvez ${ }^{\mathrm{a}}$, Eduardo $\operatorname{Costas}^{\mathrm{d}}$ and I. Emma Huertas ${ }^{\mathrm{a}}$

5 aanstituto de Ciencias Marinas de Andalucía CSIC, Polígono Rio San Pedro, E-11519,

6 Spain.

$7 \quad{ }^{\mathrm{b}}$ Instituto de Investigaciones Marinas, CSIC, Eduardo Cabello 6, E-36208 Vigo, Spain.

$8{ }^{\mathrm{c}}$ Departamento de Biología, Universidad de Cádiz, Campus Universitario Rio San

9 Pedro, E-11510, Spain.

$10{ }^{\mathrm{d}}$ Facultad de Veterinaria, Universidad Complutense de Madrid. Avenida Puerta de

11 Hierro s/n, 28040, Madrid, Spain.

\section{*Corresponding author}

Email address: $\underline{\text { susana.flecha@icman.csic.es (Susana Flecha) }}$

\section{Abstract}

The North Atlantic is the most important sink for atmospheric $\mathrm{CO}_{2}$ although there still remain uncertainties about the total amount stored by this region and the contribution of the anthropogenic $\mathrm{CO}_{2}\left(\mathrm{C}_{\mathrm{ANT}}\right)$ that is exchanged between the Mediterranean Sea and the Atlantic Ocean. During the $\mathrm{P}_{3} \mathrm{~A}_{2}$ cruise performed in October 2008 throughout the oceanic area covered by the Gulf of Cádiz and the Strait of Gibraltar, which channelizes the water exchange between the Atlantic and the Mediterranean, extensive measurements of the carbon system parameters $(\mathrm{pH}$, total alkalinity and total inorganic carbon) and others related (dissolved oxygen and nutrients) were carried out to analyse their distribution in the area. In order to study the $\mathrm{C}_{\mathrm{ANT}}$ spatial variability, three observational methods for $\mathrm{C}_{\mathrm{ANT}}$ concentration assessment $\left(\varphi \mathrm{C}_{\mathrm{T}}{ }^{\circ}, \Delta \mathrm{C}^{*}\right.$ and $\left.\operatorname{TrOCA}\right)$ were applied. The three water masses identified in the area, North Atlantic Central Water (NACW), North Atlantic Deep Water (NADW) and Mediterranean Outflow Water (MOW), were shown to contain different $\mathrm{C}_{\mathrm{ANT}}$ concentration. NADW exhibited the lowest $\mathrm{C}_{\mathrm{ANT}}$ levels whereas NACW was the most $\mathrm{C}_{\mathrm{ANT}}$ enriched. Data also indicate a net import of $\mathrm{C}_{\mathrm{ANT}}$ from the Atlantic towards the Mediterranean through Gibraltar. 
33 Specific $\mathrm{C}_{\mathrm{ANT}}$ inventories showed that MOW contributes in 8-12\% to the total specific $34 \quad \mathrm{C}_{\mathrm{ANT}}$ inventory of the Gulf of Cádiz.

\section{Keywords}

Anthropogenic $\mathrm{CO}_{2}$, Carbon storage, Water masses, Gulf of Cádiz, Strait of Gibraltar, Mediterranean Sea.

\section{Introduction}

43 Since the late 18th Century, carbon dioxide $\left(\mathrm{CO}_{2}\right)$ concentration in the atmosphere has been rising considerably, which is directly attributable to the fossil fuel burning and changes in land use (deforestation, agriculture, etc.) by human activity (IPCC, 2007).

46 Nevertheless, atmospheric levels are lower than expected if all the $\mathrm{CO}_{2}$ released by anthropogenic sources had remained in the atmosphere. This mismatch is due to the fact that the ocean and land biosphere have taken up a significant amount of $\mathrm{CO}_{2}$, thus acting as sinks for the anthropogenic carbon dioxide $\left(\mathrm{C}_{\mathrm{ANT}}\right)$ (Sarmiento and Gruber, 2002). It is known that the oceans represent the major of these two sinks, storing approximately $48 \%$ of the total $\mathrm{C}_{\mathrm{ANT}}$ (Sabine et al., 2004). Therefore, quantifying $\mathrm{C}_{\mathrm{ANT}}$ distribution and the total amount sequestered by the oceans is crucial to better understand the role of the oceans in the global carbon cycle and how they moderate climate change (IPCC, 2007). This analysis must be, however, conducted through empirical methods based on the use of different tracers since $\mathrm{C}_{\mathrm{ANT}}$ can not be directly measured.

Several methods for the indirect estimation of $\mathrm{C}_{\mathrm{ANT}}$ have been developed up to date. Those based in the back-calculation technique (Brewer, 1978; Chen and Millero, 1979)

60 are quite extended as they were the first algorithms defined to assess the temporal 61 variation experienced by the measured inorganic carbon since a water mass was 62 originally formed. Such variation is due to the contribution of the organic matter oxidation-reduction processes and the calcium carbonate dissolution-precipitation.

64 Gruber et al. (1996) improved the initial method that was developed for the Atlantic Ocean and defined the quasi-conservative carbon tracer $\Delta \mathrm{C}^{*}$, which reflects the uptake 
of $\mathrm{C}_{\mathrm{ANT}}$ and the air-sea disequilibrium present when the water mass loses contact with the atmosphere, assuming that it remains constant over time. A more recent method for $\mathrm{C}_{\mathrm{ANT}}$ computation is the TrOCA approach, which was originally proposed by Touratier and Goyet (2004b) and further improved by Touratier et al (2007). This technique considers a quasi-conservative tracer TrOCA, which combines Oxygen, inorganic Carbon, and Total Alkalinity and that is based on the conservative NO tracer (Broecker, 1974; Ríos et al., 1989; Touratier and Goyet, 2004a). Both the TrOCA approach and the $\Delta \mathrm{C}^{*}$ technique assume that below the mixed layer, the decomposition of organic matter follows a constant Redfield stoichiometry and that today's air-sea $\mathrm{CO}_{2}$ disequilibrium is identical to the one present in pre-industrial times. Current studies have indicated that the TrOCA method considerably overestimates anthropogenic carbon concentrations (Yool et al., 2011). Nevertheless, method has been still applied in our work in order to compare the data obtained with the previous results shown by Aït-Ameur and Goyet (2006) in the Gulf of Cádiz. A new parameterization , has been lately proposed by Vazquez-Rodriguez et al. (2009a), the so-called $\varphi \mathrm{C}_{\mathrm{T}}{ }^{\mathrm{o}}$ method, which represents a revision of $\Delta C^{*}$ and it is aimed at improving the assessment of $\mathrm{C}_{\mathrm{ANT}}$ inventory in the Atlantic Ocean. The main contribution of the $\varphi \mathrm{C}_{\mathrm{T}}{ }^{\mathrm{o}}$ method is the use of sub-surface layer data $(100-200 \mathrm{~m})$ to reconstruct water mass formation conditions, thereby obtaining better estimates of preformed properties instead of using other transient traces, such as CFC, to quantify the effect of the air-sea disequilibrium on the $\mathrm{C}_{\mathrm{ANT}}$ concentration.

However, regardless of the method considered for $\mathrm{C}_{\mathrm{ANT}}$ calculation, several studies have confirmed that the North Atlantic is the most important sink for atmospheric $\mathrm{CO}_{2}$ (Takahashi, 2009; Sabine et al., 2004), although there still remain uncertainties about the total amount stored by this region. In the past, the contribution of areas such as marginal seas, semi-enclosed seas and continental shelves to the global $\mathrm{C}_{\mathrm{ANT}}$ inventories was understudied. Nevertheless, recent studies that evaluate the $\mathrm{CO}_{2}$ sink capacity of these areas have demonstrated that they take up larger amounts of $\mathrm{C}_{\mathrm{ANT}}$ which contribute significantly to the overall global $\mathrm{C}_{\mathrm{ANT}}$ inventories (Tanhua et al., 2009; Schneider et al., 2010; Lee et al., 2011 ). Therefore, there is a clear research need to accurately quantify the amount of carbon that is captured by the total coastal ocean and subsequently transferred to the open sea. In response to this increasing interest, several studies have been carried out in the coastal area comprised by the Gulf of Cádiz and the 
100 Strait of Gibraltar (Aït-Ameur and Goyet, 2006; Huertas et al., 2006; 2009; de la Paz et

101 al., 2008, 2011; Ribas-Ribas et al., 2011). Data attained by these studies indicate that

102 this region acts as a moderate sink for atmospheric $\mathrm{CO}_{2}$ and that a net export of total

103 inorganic carbon occurs from the Mediterranean to the Atlantic. On the other hand,

104 there have been contradicting results about the concentration of $\mathrm{C}_{\mathrm{ANT}}$ that is exchanged

105 between both basins (Aït-Ameur and Goyet, 2006; Huertas et al., 2006; 2009). These

106 discrepancies may be related to the different methods used to obtain $\mathrm{C}_{\mathrm{ANT}}$

107 concentrations, as the TrOCA approach seems to overestimate Mediterranean waters

108 anthropogenic carbon levels. Therefore, the main aim of this work was to examine the

109 spatial variability of the $\mathrm{C}_{\mathrm{ANT}}$ in the Gulf of Cádiz considering all the water masses

110 present in the area, in order to gain insights on the role of the Strait of Gibraltar in the

111 fluxes of the anthropogenic carbon. This analysis was performed by applying all the

112 aforementioned $\mathrm{C}_{\mathrm{ANT}}$ calculation techniques not only with the aim at comparing the

113 results provided by the different methods currently available and generally applied but

114 also to allow the comparison with data reported in the past in this geographic zone by

115 using the TrOCA approach.. Furthermore, a $\mathrm{C}_{\mathrm{ANT}}$ inventory for the whole area is

116 provided, with the relative contribution of the outflow of Mediterranean water to the

117 specific inventory being also given.

\section{$119 \quad 1.1$ Study Area}

121 The oceanic area covered by the Gulf of Cádiz and the Strait of Gibraltar, located southwest of the Iberian Peninsula (Fig. 1), plays a relevant role in the general circulation of the North Atlantic owing to the channelization of the water exchange between the Atlantic and the Mediterranean Sea (Péliz et al., 2009; Criado-Aldeanueva et al., 2009). Thus, the entrainment of North Atlantic Central Water (NACW) by the Mediterranean outflow (MOW) as it descends the northern slope of the Gulf of Cádiz markedly contributes to the generation of the Azores current and also drives upper slope currents in the basin (Péliz et al., 2009).

The Strait of Gibraltar is a narrow and shallow channel with an east-west orientation of

130 a minimum width of $14 \mathrm{~km}$ (the Tarifa Narrows, TN in Fig. 1) and an average depth of

$131600 \mathrm{~m}$, although the main sill of the Strait (Camarinal Sill, CS in Fig. 1) is hardly $300 \mathrm{~m}$

132 depth and imposes a severe constrain for the ventilation of deep Mediterranean waters.

133 On the other hand, the adjacent Gulf of Cádiz is divided into two different portions by 
134 Cape Santa Maria (CSM) (Fig. 1), with each of these halves presenting different

135 topographic characteristics. West of CSM, the continental shelf is narrow and the sea 136 bottom is characterized by the presence of submarine canyons. On the contrary, east of

137 the cape the continental shelf becomes wider and hosts important rivers whose mouths

138 provide the basin with freshwater and nutrients that control primary production in the

139 coastal fringe (Prieto et al., 2009). As underlined above, the circulation of water masses

140 in the Gulf is markedly controlled by the Mediterranean-Atlantic exchange that takes

141 place in the Strait of Gibraltar. The saltier and denser MOW moves westwards in depth,

142 being distinguishable through two main cores centred at about 800 and $1200 \mathrm{~m}$ depth.

143 This subdivision is probably due to the bottom topography that channels different

144 branches along certain isobaths (Ambar and Howe, 1979; Serra and Ambar, 2002). In

145 addition, a third shallower core can be detected at depths around $500 \mathrm{~m}$ in the

146 continental shelf (Ambar et al., 2002). In contrast, Atlantic waters flow eastward to the

147 Mediterranean Sea, occupying the upper layer in the Strait of Gibraltar. The confluence

148 of both water bodies determines the two layer circulation scheme found in the Strait.

149 The exchange of waters is mainly driven by the water deficit occurring in the

150 Mediterranean basin, as the excess of evaporation over precipitation and river run off

151 forces the Atlantic jet to progress towards the Mediterranean Sea to compensate water

152 losses (Bryden et al., 1994).

153 The presence of NACW in the area is evident below $100 \mathrm{~m}$ depth, as described in 154 previous studies (Navarro et al., 2006). This water mass has been categorized in two 155 varieties, such as the warmer Eastern North Atlantic Central Water of subtropical origin $156\left(\right.$ ENAC $\left._{t}\right)$ and the colder subpolar Eastern North Atlantic Central Water $\left(\right.$ ENAC $\left._{\mathrm{s}}\right)($ Ríos 157 et al., 1992; Pollard et al., 1996; Pérez et al., 2001; Alvarez et al., 2005). At shallower 158 depths, NACW is modified by the atmospheric interaction and it has been defined as 159 North Atlantic Surface Water (Gascard and Richez, 1985). Furthermore, the North 160 Atlantic Deep Water (NADW) can be found at depths greater than $1500 \mathrm{~m}$ (Emery and 161 Meincke, 1986; Alvarez et al., 2005) associated with a depth-decreasing thermohaline 162 properties (Ambar et al., 2002).

\subsection{Sampling}


168 The $\mathrm{P}_{3} \mathrm{~A}_{2}$ oceanographic cruise was conducted on board the R.V. Hespérides from the

$16904^{\text {th }}$ to the $22^{\text {nd }}$ of October 2008 . A macroscale study was completed in a sampling grid

170 composed by 45 stations distributed from CSM to the Strait of Gibraltar (Fig.1). At each

171 station CTD profiles were obtained with a SeaBird SBE 911, followed by collection of

172 water samples with rosette at different depths (from $5 \mathrm{~m}$ up to $2000 \mathrm{~m}$ or bottom

173 depth) in order to determine the spatial distribution of several biogeochemical variables,

174 such as total alkalinity, $\mathrm{pH}$, dissolved oxygen and inorganic nutrients (nitrite, nitrate,

175 phosphate and silicate).

\subsection{Measurements}

\subsubsection{Total Alkalinity}

180

Total alkalinity $\left(\mathrm{A}_{\mathrm{T}}\right)$ was measured with a Metrohm 794 Titroprocessor following the method described by Mintrop et al. (2000). Water samples were taken from the Niskin bottles and preserved in $500 \mathrm{~mL}$ borosilicate bottles poisoned with $100 \mu \mathrm{L}$ of $\mathrm{HgCl}_{2}$ saturated aqueous solution and kept until subsequent onboard and onshore analysis. Accuracy of $\mathrm{A}_{\mathrm{T}}$ determination was calculated from regular measurements of 2 batches (batch \# 85 and 89) of Certified Reference Material (CRM supplied by Prof. Andrew Dickson, Scripps Institution of Oceanography, La Jolla, CA, USA), resulting in \pm 2 $\mu \mathrm{mol} \mathrm{kg}{ }^{-1}$.

\subsection{2 pH}

$\mathrm{pH}$ was measured following the spectrophotometric method of Clayton and Byrne (1993) using m-cresol purple as the indicator, and consequently, the scale used was the total scale. Samples were collected directly from the rosette in $10 \mathrm{~cm}$ path-length optical glass cells and measurements were carried out onboard with a Shimadzu UV-2401PC spectrophotometer containing a $25^{\circ} \mathrm{C}$-thermostated cells holder.

197 This method has been proved to have an accuracy of $\pm 0.003 \mathrm{pH}$ units (Clayton and 198 Byrne, 1993). Accuracy of our $\mathrm{pH}$ determinations was calculated from regular measurements of 2 CRMs batches (\# 85 and \# 89). From both $\mathrm{pH}$ and $\mathrm{A}_{\mathrm{T}}$ values, the concentration of inorganic carbon $\left(\mathrm{C}_{\mathrm{T}}\right)$ was calculated using the dissociation constants from Mehrbach et al. (1973) refitted by Dickson and Millero (1987). 


\subsubsection{Dissolved Oxygen}

205 Dissolved oxygen was determined following the Winkler method (Winkler, 1888). 206 Seawater was taken in sealed flasks directly from the Niskin bottles and stored in 207 darkness for at least $24 \mathrm{~h}$. Analysis was performed by potentiometric determination 208 using a Metrohm 794 Titroprocessor, with an estimated error of $\pm 1 \mu \mathrm{mol} \mathrm{kg}{ }^{-1}$.

\subsubsection{Nutrients}

212 Two $5 \mathrm{~mL}$ replicates of filtered seawater (GF/F Whatman filters) were taken and stored 213 at $-20^{\circ} \mathrm{C}$ until onshore laboratory analysis. Concentration of $\mathrm{NO}_{2}, \mathrm{NO}_{3}, \mathrm{PO}_{4}$ and $\mathrm{Si}$ $214(\mathrm{OH})_{4}$ were obtained following the techniques described by Grasshoff et al. (1983) with 215 a Skalar $\mathrm{San}^{++}$System autoanalyser.

\subsection{Calculation of $\mathbf{C}_{\mathrm{ANT}}$ concentration}

219 As already indicated, several methods were applied to calculate $\mathrm{C}_{\mathrm{ANT}}$ in the study 220 region: the TrOCA approach with the set of parameters proposed by Touratier and 221 Goyet (2004b) and with the latter improvements of Touratier et al. (2007), designated 222 here as $\mathrm{TrOCA}_{2004}$ and $\mathrm{TrOCA}_{2007}$ respectively; the back-calculation technique $\left(\Delta \mathrm{C}^{*}\right)$ 223 and the $\varphi \mathrm{C}_{\mathrm{T}}{ }^{\mathrm{o}}$ method. The original $\mathrm{TrOCA}_{2004}$ parameterization (Touratier and Goyet 224 2004b) was exclusively used to compare the results attained in this study with previous 225 estimations reported in the area based on such method (Aït-Ameur and Goyet, 2006). 226 Regardless of the calculation technique applied, the first $100 \mathrm{~m}$ of the water column 227 were excluded for $\mathrm{C}_{\mathrm{ANT}}$ assessments and hence only data obtained in stations with 228 waters deeper than $100 \mathrm{~m}$ were considered.

$229 \mathrm{C}_{\mathrm{ANT}}(\mathrm{TrOCA})$ has been computed using the following relationship

$230 \quad \mathrm{C}_{\text {ant }}\left(\operatorname{TrOCA}_{2004 ; 2007}\right)=\frac{\operatorname{TrOCA}^{-\mathrm{TrOCA}^{\circ}}}{\mathrm{a}}$,

231 where TrOCA represents a semi-conservative tracer based on the Redfield oxidation232 reduction ratios of organic matter, calculated as follows:

$233 \operatorname{TrOCA}_{2004}=\mathrm{O}_{2}+\mathrm{aC}_{\mathrm{T}}-0.6 \mathrm{~A}_{\mathrm{T}}, \mathrm{TrOCA}_{2007}=\mathrm{O}_{2}+\mathrm{a}\left(\mathrm{C}_{\mathrm{T}}-1 / 2 \mathrm{~A}_{\mathrm{T}}\right)$,

234 and $\operatorname{TrOCA}^{\circ}$ is defined as the pre-industrial TrOCA: 
$\operatorname{TrOCA}_{2004}^{\circ}=1505.04 \mathrm{e}^{(-\theta / 89.04)}, \operatorname{TrOCA}_{2007}^{\circ}=\mathrm{e}^{\left(7.511+\left(1.087 \times 10^{-2}\right) \theta-\left(7.81 \times 10^{-5} / \mathrm{A}_{\mathrm{T}}^{2}\right)\right)}$,

236 where the constant $a$ is equal to 1.2 and 1.279 for the $\mathrm{TrOCA}_{2004}$ and the $\mathrm{TrOCA}_{2007}$ parameterizations respectively.

For the back-calculation technique, the following equation was used:

$\mathrm{C}_{\mathrm{ANT}}\left(\Delta \mathrm{C}^{*}\right)=\mathrm{C}_{\mathrm{T}}-\mathrm{AOU} / \mathrm{R}_{\mathrm{C}}-1 / 2\left(\Delta \mathrm{A}_{\mathrm{T}}+\mathrm{AOU} / \mathrm{R}_{\mathrm{N}}\right)-\mathrm{C}_{\mathrm{T} 278}^{\circ}-\Delta \mathrm{C}_{\mathrm{dis}}$,

where $\mathrm{C}_{\mathrm{T}}$ is the dissolved inorganic carbon concentration of the sample expressed in $\mu \mathrm{mol} \mathrm{kg} \mathrm{kg}^{-1}$ and AOU stands for Apparent Oxygen Utilization, which was calculated using the oxygen saturation equation of Benson and Krause (1984). The stoichiometric coefficients $\mathrm{R}_{\mathrm{C}}\left(-\Delta \mathrm{O}_{2} / \Delta \mathrm{C}\right)=1.45$ and $\mathrm{R}_{\mathrm{N}}\left(-\Delta \mathrm{O}_{2} / \Delta \mathrm{N}\right)=10.6$ of Anderson and Sarmiento (1994) were taken. AOU/ $R_{C}$ corresponds to the $C_{T}$ increase due to organic matter oxidation and $1 / 2\left(\Delta \mathrm{A}_{\mathrm{T}}+\mathrm{AOU} / \mathrm{R}_{\mathrm{N}}\right)$ accounts for the $\mathrm{C}_{\mathrm{T}}$ change due to $\mathrm{CaCO}_{3}$ dissolutionprecipitation, where $\Delta \mathrm{A}_{\mathrm{T}}=\mathrm{A}_{\mathrm{T}}-\mathrm{A}_{\mathrm{T}}^{\circ}$ is the total alkalinity variation since the water mass was formed. Preformed alkalinity $\left(\mathrm{A}_{\mathrm{T}}^{\circ}\right)$ and the disequilibrium term that stands for the air-sea $\mathrm{CO}_{2}$ difference expressed in terms of $\mathrm{C}_{\mathrm{T}}\left(\Delta \mathrm{C}_{\mathrm{dis}}\right)$, were obtained for each water sample from the mixing proportion of the different water masses. This was carried out by an extended optimum multiparameter analysis (eOMP) (Poole and Tomczak, 1999). The $A_{T}^{\circ}$ type values for the Atlantic Waters were calculated using the approach proposed by Perez et al. (2002) while those by Rhein and Hinrichsen (1993) and Santana-Casiano et al. (2002) were used for the MOW. $\mathrm{C}_{\mathrm{T} 278}^{\circ}$ represents the $\mathrm{C}_{\mathrm{T}}$ in equilibrium with the preindustrial atmospheric $\mathrm{CO}_{2}$ molar fraction of $278 \mathrm{ppm}$ and was calculated using the dissociation constants of Merbach et al. (1973) refitted by Dickson and Millero (1987). $\Delta \mathrm{C}_{\mathrm{dis}}$ for both NACW and NADW was considered to be $-12 \pm 5$ $\mu \mathrm{mol} \mathrm{kg}{ }^{-1}$ and $-10 \pm 8 \mu \mathrm{mol} \mathrm{kg}{ }^{-1}$, respectively (Lee et al. 2003) whereas for the MOW $\Delta \mathrm{C}_{\text {dis }}$ was obtained from Huertas et al. (2009), which sets $\Delta \mathrm{C}_{\text {dis }}$ in $0 \pm 5 \mu \mathrm{mol} \mathrm{kg}^{-1}$ using the CFC data given by Rhein and Hinrichsen (1993). As for the $\varphi \mathrm{C}_{\mathrm{T}}{ }^{\circ}$ method (VazquezRodriguez et al. 2009a), new $\mathrm{A}_{\mathrm{T}}^{\circ}$ and $\Delta \mathrm{C}_{\mathrm{dis}}$ parameterizations were included in the equation based on a 100-200 m depth surface layer that is taken as a reference for reconstructing water mass formation conditions. Accordingly, the NO and PO conservative tracers defined by Broecker (1974) and the preformed silicate $\left(\mathrm{S}_{\mathrm{i}}{ }^{\circ}\right)$ provided by Perez et al. (2002) were used. For the term $\Delta \mathrm{C}_{\mathrm{dis}}$, a distinction depending on different potential temperature $(\theta)$ intervals was made in the case of Atlantic waters 
whereas for the MOW $(\mathrm{S}>36.5), \mathrm{A}_{\mathrm{T}}^{\circ}$ and $\Delta \mathrm{C}_{\mathrm{dis}}$ were obtained by eOMP analysis. The different water masses found in the area were defined in the eOMP analysis by several water types (WT): WT1 and WT2 correspond to the two different varieties of NACW (ENACWt and ENACWs, respectively), WT3 designs NADW and WT4 marks MOW, as summarized in Table 1.

273 Therefore, the $\mathrm{C}_{\mathrm{ANT}}^{\varphi}$ calculation equation can be summarized as follows

$$
\mathrm{C}_{\mathrm{ANT}}\left(\varphi \mathrm{C}_{\mathrm{T}}^{0}\right)=\frac{\Delta \mathrm{C}^{*}-\Delta \mathrm{C}_{\mathrm{dis}}^{\mathrm{t}}}{1+\varphi\left|\Delta \mathrm{C}_{\mathrm{dis}}^{\mathrm{t}}\right| / \mathrm{C}_{\mathrm{ant}}^{\mathrm{sat}}},
$$

with $\Delta \mathrm{C}^{*}=\mathrm{C}_{\mathrm{T}}-\mathrm{AOU} / \mathrm{R}_{\mathrm{C}}-\Delta \mathrm{Ca}-\mathrm{C}_{\mathrm{T} 278}^{\circ}$ where $\Delta \mathrm{Ca}$ is the term related to the $\mathrm{CaCO}_{3}$ dissolution, since $\Delta \mathrm{Ca}=0.5\left(\mathrm{PA}_{\mathrm{T} \text {,observed }}-\mathrm{PA}_{\mathrm{T}}^{\circ}\right)$ with $\mathrm{PA}_{\mathrm{T}}=\mathrm{A}_{\mathrm{T}}+\mathrm{NO}_{3}+\mathrm{PO}_{4}$ and $\mathrm{PA}_{\mathrm{T}}^{\circ}=\mathrm{A}_{\mathrm{T}}^{\circ}+\mathrm{NO}_{3}^{\circ}+\mathrm{PO}_{4}^{\circ}$, being $\mathrm{NO}_{3}^{\circ}=\mathrm{NO}_{3}-\mathrm{AOU} / 9$ and $\mathrm{PO}_{4}^{\circ}=\mathrm{PO}_{4}-\mathrm{AOU} / 135$. The $\mathrm{O}_{2}: \mathrm{N}=9$ and $\mathrm{O}_{2}: \mathrm{P}=135$ Redfield ratios proposed by Broecker (1974) were taken. Furthermore, in the $\mathrm{C}_{\mathrm{ANT}}\left(\varphi \mathrm{C}_{\mathrm{T}}^{0}\right)$ equation, the constant term $\varphi$ is a proportionality factor and equals the ratio between the temporal variability of the air-sea disequilibrium of $\mathrm{CO}_{2}$ from the time of pre-industrial water mass formation to the time " $\mathrm{t}$ " $\left(\Delta \Delta \mathrm{C}_{\mathrm{dis}}\right)$, with the disequilibrium at the time " $\mathrm{t}$ " being $\Delta \mathrm{C}_{\mathrm{dis}}^{\mathrm{t}}$. Finally, $\mathrm{C}_{\text {ant }}^{\text {sat }}$ represents the anthropogenic carbon saturation referred to a $\mathrm{xCO}_{2}$ air of $384 \mathrm{ppm}$, which is taken from measurements performed at the meteorological station of the Lampedusa (Italy, Cooperative Air Sampling Network of the NOAA/ESRL Global Monitoring Division) and it is included to account for the effects of temperature and salinity on the solubility of $\mathrm{C}_{\mathrm{ANT}}$ in the different water masses.

In order to estimate the uncertainty associated to the $\mathrm{C}_{\mathrm{ANT}}$ calculation techniques an error propagation analysis was conducted for each method. The error for $\mathrm{C}_{\mathrm{ANT}}$ assessments using the $\mathrm{TrOCA}_{2004}$ and the $\mathrm{TrOCA}_{2007}$ parameterizations were $\pm 5.3 \mu \mathrm{mol}$ $\mathrm{kg}^{-1}$ and $\pm 5.5 \mu \mathrm{mol} \mathrm{kg}{ }^{-1}$, respectively; $\pm 6.1 \mu \mathrm{mol} \mathrm{kg}{ }^{-1}$ when the $\Delta \mathrm{C}^{*}$ technique was applied and $\pm 5.6 \mu \mathrm{mol} \mathrm{kg}{ }^{-1}$ in the case of the $\varphi \mathrm{C}_{\mathrm{T}}{ }^{\mathrm{o}}$ method. In previous works, the overall estimated $\mathrm{C}_{\mathrm{ANT}}$ uncertainties ranged from \pm 3 to $5.9 \mu \mathrm{mol} \mathrm{kg}^{-1}$ for the $\mathrm{TrOCA}_{2004}$ approach (Touratier et al. 2004b), \pm 6.2 for the $\mathrm{TrOCA}_{2007}$ parameterization (Touratier et al. 2007), \pm 9 for the $\Delta C^{*}$ technique (Gruber et al. 1996) and \pm 5.2 for the $\varphi C_{T}{ }^{\circ}$ method (Vazquez-Rodriguez et al. 2009a). 


\section{Results and Discussion}

299

\subsection{Water masses and carbon system parameters in the study area.}

302 Three water masses were clearly identified in the Gulf of Cádiz according to their 303 different thermohaline properties (Fig.2a): NACW, NADW and MOW. NACW, located 304 above $500 \mathrm{~m}$ depth, was well defined with a temperature range from 11 to $18{ }^{\circ} \mathrm{C}$ and 305 salinity values around 35.5-36.3. This water mass showed a linear behaviour for the 306 isopicnals interval of $26.6 \mathrm{~kg} \mathrm{~m}^{-3} \leq \sigma_{\theta} \leq 27.3 \mathrm{~kg} \mathrm{~m}^{-3}$, as described in Criado-Aldeanueva 307 et al. (2006). The MOW signal could be detected throughout the entire study area and 308 up to $1500 \mathrm{~m}$ depth (Figs. 5f, 6f). In particular, MOW in the Strait of Gibraltar is 309 defined by a salinity of 38.5 and a temperature value of $13^{\circ} \mathrm{C}$ (Figs. 4b-c) (Gascard and 310 Richez 1985; Garcia-Lafuente et al. (2007) whereas in the Gulf of Cadiz was clearly 311 evident at a pressure of around 1000 dbar because of a salinity and potential temperature 312 increase (Fig. 3b-c). This signal corresponds to the lower core of the MOW (Fig. 5f) 313 (Ambar and Howe, 1979; Serra and Ambar, 2002). In contrast, NADW was found in a 314 reduced number of deep stations (depth>1500 m) located in the southwestern part of the 315 surveyed region (Fig. 5e, 6e). This water mass was previously described in the Iberian 316 Basin by Alvarez et al. (2005) with salinity and temperature values around 34.9 and 2.4 $317{ }^{\circ} \mathrm{C}$, respectively. In our study, NADW was slightly modified as it showed salinity and 318 temperature values around $35^{\circ} \mathrm{C}$ and $5^{\circ} \mathrm{C}$ respectively (Figs. $3 b-c, 4 b-c$ ).

319 All the water masses identified were also characterized by specific carbonate properties, 320 as the variability of $\mathrm{A}_{\mathrm{T}}$, AOU and $\mathrm{C}_{\mathrm{T}}$ (Figs. 2b-d) was well correlated with the 321 distribution of the different water masses. Due to the shallower location of the NACW

322 (Figs. 5d, 6d), its thermohaline properties suffer modifications caused by the air-sea 323 interactions and river discharges (Criado-Aldeanueva et al., 2009), which resulted in the 324 highest variability found for these parameters within the same water mass (Figs. 2b-d). 325 Moreover, the pattern of AOU allowed to distinguish the presence of the two varieties 326 of the NACW described in the area: the ENAC $_{t}$, which is oxygen saturated, was thereby 327 characterized by the lowest AOU levels at about $6 \mu \mathrm{mol} \mathrm{kg}^{-1}$ (Fig. 2c), coinciding with 328 previous reports (Ait-Ameur and Goyet, 2006) and the ENAC $_{\mathrm{s}}$ which is located below 329 the former, and exhibited an increase in the AOU levels (Fig. 2c). Perez et al. (2001) 
330 attributed this deeper AOU maximum to the remineralization of organic matter in the 331 African coast linked to the northwest African upwelling system. Within the NACW 332 layer, $\mathrm{A}_{\mathrm{T}}$ and $\mathrm{C}_{\mathrm{T}}$ showed intermediate levels in relation to the total measurements, with 333 average values around $2360 \pm 2$ and $2130 \pm 2 \mu \mathrm{mol} \mathrm{kg}^{-1}$, respectively (Figs. 2b,d, 3d-e, 4d334 e). As expected, the highest $\mathrm{A}_{\mathrm{T}}\left(2576 \pm 6 \mu \mathrm{mol} \mathrm{kg}{ }^{-1}\right)$ and $\mathrm{C}_{\mathrm{T}}$ contents $\left(2317 \pm 5 \mu \mathrm{mol} \mathrm{kg}{ }^{-}\right.$ $335^{1}$ ) were found in the MOW located in the western side of the Strait (Figs. 2b-d). In the 336 vertical sections of the N-S and W-E transects, the biogeochemical properties of the 337 MOW were also evident in the lower core (Figs. 3d-f, 5f) and in the western part of the 338 Strait (Figs. 4d-f, 6f), with values that coincide with those reported by Aït-Ameur and 339 Goyet (2006) and Huertas et al. (2009) in the area. The elevated AOU levels of about 80 $340 \mu \mathrm{mol} \mathrm{kg}{ }^{-1}$ within this layer indicated the lower oxygen concentrations present in the 341 MOW due to the active remineralisation of organic matter occurring in the 342 Mediterranean basin (Huertas et al., 2009).

343 On the other hand, the $\mathrm{A}_{\mathrm{T}}$ and $\mathrm{C}_{\mathrm{T}}$ signatures inside the NADW showed lower values 344 equivalent to $2329 \pm 7 \mu \mathrm{mol} \mathrm{kg}{ }^{-1}$ and $2167 \pm 2 \mu \mathrm{mol} \mathrm{kg}{ }^{-1}$, respectively (Fig. $2 \mathrm{~b}, \mathrm{~d}$ ). In fact, 345 data plotted in the vertical sections of the transects revealed a decrease of these 346 properties with depth (Figs. 3d-e, 4d-e) due to the presence of this water mass (Figs. 5e, $3476 \mathrm{e})$. It is also worth mentioning that the high AOU values $\left(\sim 80 \mu \mathrm{mol} \mathrm{kg}^{-1}\right)$ detected in 348 this water mass (Fig. 2c) can be related to the ageing of water masses that results in a 349 simultaneous increase in AOU, nitrate and phosphate owing to the mineralization of 350 organic matter (van Aken, 2000).

352 The linear relationship between salinity and $\mathrm{A}_{\mathrm{T}}$ obtained for the whole region was calculated at a salinity reference of 35 in order to remove spatio-temporal changes. The equation obtained $\left(\mathrm{A}_{\mathrm{T}}=\left[(84.3 \pm 1.6) *(\mathrm{~S}-35)-(2277 \pm 2), \mathrm{r}^{2}=0.95, \mathrm{n}=156\right]\right.$ indicated that mixing is the main controlling factor for the $\mathrm{A}_{\mathrm{T}}$ distribution, in a similar way as in Santana-Casiano et al., (2002) and Huertas et al., (2009). These authors reported linear relationships of $\mathrm{A}_{\mathrm{T}}=2353( \pm 0.4)+92.28( \pm 0.31)(\mathrm{S}-36.0)\left(\mathrm{r}^{2}=0.998\right)$ and $\mathrm{A}_{\mathrm{T}}=92.98 \times \mathrm{S}-$ $993\left(r^{2}=0.989\right)$ for the Gulf and the Strait, respectively. The new relationship attained here was based on data collected in a wider area, which is influenced by the presence of water masses with lower salinity, such as the NADW, which is absent in the Strait. This circumstance may explain the reduction in the slope and the slight diminution in the correlation coefficient compared to the ones reported by previous works. 
366 The vertical distribution of $\mathrm{C}_{\mathrm{ANT}}$ calculated using the $\mathrm{TrOCA}_{2007}$, the $\Delta \mathrm{C}^{*}$ and the $\varphi \mathrm{C}_{\mathrm{T}}{ }^{\mathrm{o}}$ methods is plotted in Fig. 5 for a N-S section and in Fig. 6 for an E-W section. The red transects indicated in Figs. 3a and $4 \mathrm{a}$ were chosen as representatives of all the legs sampled.

370 In the N-S section, the spatial pattern of $\mathrm{C}_{\mathrm{ANT}}$ was similar regardless of the method used for computation, as all of them resulted in a vertical decreasing gradient (Figs. 5a-c). The maximum concentrations of $\mathrm{C}_{\mathrm{ANT}}$ were consistently located in $100 \mathrm{~m}$ depth waters (50-60 $\mu \mathrm{mol} \mathrm{kg} \mathrm{kg}^{-1}$, where the highest proportion of NACW was present (Fig. 5d). In contrast, the lowest $\mathrm{C}_{\mathrm{ANT}}$ values were found at depths below 1500 dbar (Figs. 5a-c) due to the slight $\mathrm{C}_{\mathrm{ANT}}$ penetration into the domain of the NADW (Fig. 5e), as described by Ríos et al., 2001). Within this layer, $\mathrm{C}_{\mathrm{ANT}}$ concentrations showed concordant values between 9 and $12 \mu \mathrm{mol} \mathrm{kg}{ }^{-1}$ for all the methods applied (Figs. 5a-c). The higher salinity zone found at about 1000-1200 dbar in the continental slope (Fig. 3b) and corresponding to the lower MOW core (Fig. 5f), was characterized by an increase in

$380 \mathrm{C}_{\mathrm{ANT}}$ concentration, especially when the $\mathrm{TrOCA}_{2007}$ parameterization was used (Fig. $5 \mathrm{c})$, resulting in concentrations of $50 \mu \mathrm{mol} \mathrm{kg}{ }^{-1}$ approximately.

In the $\mathrm{E}-\mathrm{W}$ section, the distribution of $\mathrm{C}_{\mathrm{ANT}}$ (Figs. 6a-c) revealed a similar trend for the three parameterizations used except for that obtained in the Strait of Gibraltar with the $\mathrm{TrOCA}_{2007}$ approach. According to this method, the MOW located in the Strait was characterised by the highest $\mathrm{C}_{\mathrm{ANT}}$ content (Fig.6c), particularly waters with salinities $>37.5$ (Fig.4b). $\mathrm{C}_{\mathrm{ANT}} \mathrm{TrOCA}_{2007}$ concentration in the easternmost part displayed values around $63 \pm 1 \mu \mathrm{mol} \mathrm{kg}{ }^{-1}$ (Fig.6c), which declined westwards and upwards in the water column. Moreover, when the original $\mathrm{TrOCA}_{2004}$ parameterization was applied in order to compare with previous estimates (not shown), MOW exhibited average $\mathrm{C}_{\mathrm{ANT}}$ levels of $92 \pm 1 \mu \mathrm{mol} \mathrm{kg}$, whereas NADW and NACW showed $24 \pm 4 \mu \mathrm{mol} \mathrm{kg}{ }^{-1}$ and $55 \pm 1$ $\mu \mathrm{mol} \mathrm{kg}{ }^{-1}$ in good agreement with the values reported by Aït-Ameur et al. (2006).

393 Therefore, comparing both TrOCA parameterizations, the initial $\mathrm{TrOCA}_{2004}$ method 394 yielded values around $40 \%$ higher than those attained by the technique subsequently 395 refined (Fig. 6c).

396 On the contrary, when both the $\varphi \mathrm{C}_{\mathrm{T}}{ }^{\mathrm{o}}$ and $\Delta \mathrm{C}^{*}$ methods were applied in the Strait, higher

$397 \mathrm{C}_{\mathrm{ANT}}$ concentrations were detected within the NACW located in the upper layer of the 
water column, with a decreasing vertical pattern being also evidenced (Figs. 6a, c). This discrepancy can be explained by the nature of the equations, as the general TrOCA approach applies a global formula that is a function exclusively of $\theta, \mathrm{O}_{2}$ and $\mathrm{A}_{T}$ measured in situ (Eqs. 3, 4) whereas the back-calculation techniques include the computation of the pre-industrial carbon level and the disequilibrium due to the air-sea $\mathrm{CO}_{2}$ difference (Eqs. 5, 6), which are adapted regionally considering the formation of each particular water mass. This feature was already highlighted in the early analysis performed in the Strait by Huertas et al., (2009). In the rest of the surveyed region, the ranges of $\mathrm{C}_{\mathrm{ANT}}$ concentration within the NACW and NADW coincide with those observed in the $\mathrm{N}-\mathrm{S}$ transect independent of the approach applied.

408

\section{3. $\mathrm{C}_{\mathrm{ANT}}$ inventory}

410

411 The specific inventory of $\mathrm{C}_{\mathrm{ANT}}$ for the entire area was determined by integrating the average vertical $\mathrm{C}_{\mathrm{ANT}}$ profiles attained at each station from surface down to the bottom depth. Because $\mathrm{C}_{\mathrm{ANT}}$ concentrations were calculated from 100 dbar to the sea bottom,

414 the surface layer above this depth was assumed to contain a constant $\mathrm{C}_{\mathrm{ANT}}$ level equal to 415 that present at this upper limit, which also marks the winter mixing layer for Atlantic subtropical waters (Vázquez-Rodríguez et al., 2009a). This artefact for inventory computations allows to avoid the influence of the seasonal biogeochemical variability on surface $\mathrm{C}_{\mathrm{ANT}}$ estimates (Lo Monaco et al., 2005; Vázquez-Rodríguez et al., 2009a). Specific inventories calculated in the region by the different techniques showed small differences (Table 2). Nevertheless, should be taken into account in the inventory results obtained that they represent average values for the totality of the waters masses present in the area (not shown). As is shown in the Table 2, the initial TrOCA 2004 method yielded the highest specific inventory with $38.0 \pm 3.1 \mathrm{~mol} \mathrm{C} \mathrm{m}^{-2}$, whereas the rest of calculation techniques resulted in similar values, with the minimum provided by the $\varphi \mathrm{C}_{\mathrm{T}}{ }^{\circ}$ method equivalent to $33.5 \pm 3.2 \mathrm{~mol} \mathrm{C} \mathrm{m}^{-2}$. Estimates were statistically analyzed by a student's $\mathrm{t}$ test and averaged results obtained showed no statistical differences between the different methods applied.

These values are comparable to the specific inventory presented by Lee at al. (2011) for

430 the East/Japan Sea and equal to $34 \pm 5.1 \mathrm{~mol} \mathrm{C} \mathrm{m}^{-2}$. The specific inventory for the entire 431 Eastern North Atlantic comprised in the $30^{\circ} \mathrm{N}-40^{\circ} \mathrm{N}$ latitude band, where our study area 
432 is contained, has been estimated in $66.2 \mathrm{~mol} \mathrm{C} \mathrm{m}^{-2}$, using the $\Delta \mathrm{C}^{*}$ (Lee et al., 2003) and

433 in $75 \mathrm{~mol} \mathrm{C} \mathrm{m}^{-2}$ with the $\varphi \mathrm{C}_{\mathrm{T}}{ }^{\mathrm{o}}$ method (Vázquez-Rodríguez et al., 2009b). The

434 differences between such estimates and those obtained here are due to the lower volume

435 of water contained in the surveyed region in relation to that of the Eastern North

436 Atlantic, as the vertical interpolation markedly depends of the water column volume.

438 Since the main differences in the $\mathrm{C}_{\mathrm{ANT}}$ contents observed in our study were related to 439 the presence of the Mediterranean waters (Figs. 6a-c), the contribution of the MOW to 440 the specific $\mathrm{C}_{\mathrm{ANT}}$ inventory was also calculated with each technique. Results 441 summarized in Table 2 indicate that the Mediterranean supplies $8 \%$ of the total $\mathrm{C}_{\mathrm{ANT}}$ 442 specific inventory when the $\varphi \mathrm{C}_{\mathrm{T}}{ }^{\circ}$ and $\Delta \mathrm{C}^{*}$ methods were used. A small increase in this 443 contribution (11-12\%) was attained with the two TrOCA approaches, as a result of the 444 higher concentration of $\mathrm{C}_{\mathrm{ANT}}$ assigned to the MOW by both parameterizations (Fig. 6c).

\section{Conclusions}

448 The analysis of the spatial distribution of the carbon system parameters in the area 449 covered by the Gulf of Cádiz and the Strait of Gibraltar reflected the presence of 450 different water masses that were characterized by distinct biogeochemical properties. 451 The concentration of $\mathrm{C}_{\mathrm{ANT}}$ calculated for each water mass according to three estimation 452 methods resulted in small variations. The main discrepancies between the results 453 obtained by all the methods were found in the MOW, as both TrOCA approaches seem 454 to overestimate $\mathrm{C}_{\mathrm{ANT}}$ concentration within this water mass. Accordingly, slight 455 differences were found in the specific inventories with the exception of the value 456 provided by the $\mathrm{TrOCA}_{2004}$ approach. Furthermore, the quantification of the additive 457 effect of the $\mathrm{C}_{\mathrm{ANT}}$ contained in the $\mathrm{MOW}$ on that measured in Atlantic waters at 458 intermediate depths has been evidenced in this study. This work also presents new data 459 on the $\mathrm{C}_{\mathrm{ANT}}$ levels present in a coastal ocean region, whose role in the capture and 460 storage of $\mathrm{CO}_{2}$ had been underestimated in the past. These results also represent a 461 contribution to the North Atlantic specific carbon inventories.

\section{Acknowledgments}

464 The excellent co-operation of the crew of the BIO Hespérides is gratefully 465 acknowledged. We also thank María Ferrer-Marco, Simone Taglialatela and Mónica 
466 Rouco for sample collection and measurements. Funding for this work was provided by

467 the CARBOOCEAN IP (511176GOCE) of the European Commission and by the 468 Spanish Ministry of Sciences and Innovation through the projects CTM2005/01091-

469 MAR and CTM2008-05680-C02-01.

470

\section{6. References}

472

473 Aït-Ameur, N., Goyet, C., 2006. Distribution and transport of natural and anthropogenic

$474 \mathrm{CO}_{2}$ in the Gulf of Cadiz. Deep-Sea Research Part II-Topical Studies in Oceanography $475 \quad 53,1329-1343$

476 Alvarez, M., Perez, F.F., Shoosmith, D.R., Bryden, H.L., 2005. Unaccounted role of 477 Mediterranean Water in the drawdown of anthropogenic carbon. Journal of Geophysical 478 Research-Oceans 110

479 Ambar, I., Howe, M.R., 1979. Observations of the Mediterranean Outflow .2. Deep 480 circulation in the vicinity of the Gulf of Cadiz. Deep-Sea Research-Part I481 Oceanographic Research Papers 26, 555-568

482 Ambar, I., Serra, N., Brogueira, M.J., Cabecadas, G., Abrantes, F., Freitas, P., 483 Goncalves, C., Gonzalez, N., 2002. Physical, chemical and sedimentological aspects of 484 the Mediterranean outflow off Iberia. Deep-Sea Research Part II-Topical Studies in 485 Oceanography 49, 4163-4177

486 Anderson, L.A., Sarmiento, J.L., 1994. Redfield ratios of remineralization determined 487 by nutrient data analysis. Global Biogeochemical Cycles $8,65-80$

488 Benson, B.B., Krause, D., 1984. The concentration and isotopic fractionation of oxygen 489 dissolved in fresh-water and seawater in equilibrium with the atmosphere. Limnology 490 and Oceanography 29, 620-632

491 Brewer, P.G., 1978. Direct observation of oceanic $\mathrm{CO}_{2}$ increase. Geophysical Research 492 Letters 5, 997-1000

493 Broecker, W.S., 1974. NO a conservative water-mass tracer. Earth and Planetary 494 Science Letters 23, 100-107

495 Bryden, H.L., Candela, J., Kinder, T.H., 1994. Exchange through the Strait of Gibraltar. 496 Progress in Oceanography 33, 201-248

497 Clayton, T.D., Byrne, R.H., 1993. Spectrophotometric seawater pH measurements- total 498 hygrogen scale calibration of m-cresol purple ant at-sea results. Deep-Sea Research Part 499 I-Oceanographic Research Papers 40, 2115-2129 
500 Criado-Aldeanueva, F., Garcia-Lafuente, J., Navarro, G., Ruiz, J., 2009. Seasonal and

501 interannual variability of the surface circulation in the eastern Gulf of Cadiz (SW

502 Iberia). Journal of Geophysical Research-Oceans 114

503 Criado-Aldeanueva, F., Garcia-Lafuente, J., Vargas, J.M., Del Rio, J., Vazquez, A.,

504 Reul, A., Sanchez, A., 2006. Distribution and circulation of water masses in the Gulf of

505 Cadiz from in situ observations. Deep-Sea Research Part II-Topical Studies in

506 Oceanography 53, 1144-1160

507 Chen, C.T., Millero, F.J., 1979. Gradual increase of oceanic carbon dioxide. Nature 277, $508 \quad 205-206$

509 de la Paz, M., Debelius, B., Macias, D., Vazquez, A., Gomez-Parra, A., Forja, J.M., 510 2008. Tidal-induced inorganic carbon dynamics in the Strait of Gibraltar. Continental 511 Shelf Research 28, 1827-1837

512 de la Paz, M., Huertas, M.E., Padín, X.-A., Gónzalez-Dávila, M., Santana-Casiano, M.,

513 Forja, J.M., Orbi, A., Pérez, F.F., Ríos, A.F., 2011. Reconstruction of the seasonal cycle

514 of air-sea $\mathrm{CO}_{2}$ fluxes in the Strait of Gibraltar. Marine Chemistry In Press, Corrected

515 Proof

516 Dickson, A.G., Millero, F.J., 1987. A comparison of the equilibrium-constants for the

517 dissociation of carbonic-acid in seawater media. Deep-Sea Research Part I-

518 Oceanographic Research Papers 34, 1733-1743

519 Emery, W.J., Meincke, J., 1986. Global Water Masses - Summary and Review.

520 Oceanologica Acta 9, 383-391

521 Garcia-Lafuente, J., Roman, A.S., del Rio, G.D., Sannino, G., Garrido, J.C.S., 2007.

522 Recent observations of seasonal variability of the Mediterranean outflow in the Strait of

523 Gibraltar. Journal of Geophysical Research-Oceans 112

524 Gascard, J.C., Richez, C., 1985. Water masses and circulation in the Western Alboran

525 Sea and in the Strait of Gibraltar. Progress in Oceanography 15, 157-216

526 Grasshoff, K., Ehrhard, M., Kremling, K., 1983. Determination of nutrients. In:

527 Methods of Seawater Analysis, 2nd ed. Verlag Chemie, Weinheim.

528 Gruber, N., Sarmiento, J.L., Stocker, T.F., 1996. An improved method for detecting

529 anthropogenic $\mathrm{CO}_{2}$ in the oceans. Global Biogeochemical Cycles 10, 809-837

530 Huertas, I.E., Navarro, G., Rodriguez-Galvez, S., Lubian, L.M., 2006. Temporal 531 patterns of carbon dioxide in relation to hydrological conditions and primary production 532 in the northeastern shelf of the Gulf of Cadiz (SW Spain). Deep-Sea Research Part II533 Topical Studies in Oceanography 53, 1344-1362 
534 Huertas, I.E., Rios, A.F., Garcia-Lafuente, J., Makaoui, A., Rodriguez-Galvez, S.,

535 Sanchez-Roman, A., Orbi, A., Ruiz, J., Perez, F.F., 2009. Anthropogenic and natural

$536 \mathrm{CO}_{2}$ exchange through the Strait of Gibraltar. Biogeosciences 6, 647-662

537 IPCC, 2007. Climate Change 2007: The Physical Science Basis, Contribution of

538 Working Group I to the Fourth Assessment Report of the Intergovernmental Panel on

539 Climate Change. Cambridge University Press, Cambridge, United Kingdom. New York,

540 NY, USA.

541 Lee, K., Choi, S.D., Park, G.H., Wanninkhof, R., Peng, T.H., Key, R.M., Sabine, C.L.,

542 Feely, R.A., Bullister, J.L., Millero, F.J., Kozyr, A., 2003. An updated anthropogenic

$543 \mathrm{CO}_{2}$ inventory in the Atlantic ocean. Global Biogeochemical Cycles 17

544 Lee, K., Sabine, C.L., Tanhua, T., Kim, T.W., Feely, R.A., Kim, H.C., 2011. Roles of 545 marginal seas in absorbing and storing fossil fuel $\mathrm{CO}_{2}$. Energy \& Environmental 546 Science 4, 1133-1146

547 Lo Monaco, C., Goyet, C., Metzl, N., Poisson, A., Touratier, F., 2005. Distribution and 548 inventory of anthropogenic $\mathrm{CO}_{2}$ in the Southern Ocean: Comparison of three data-based 549 methods. Journal of Geophysical Research-Oceans 110

550 Mehrbach, C., Culberso.Ch, Hawley, J.E., Pytkowic.Rm, 1973. Measurements of 551 apparent dissociation-constants of carbonic-acid in seawater at atmospheric-pressure.

552 Limnology and Oceanography 18, 897-907

553 Mintrop, L., Perez, F.F., Gonzalez-Davila, M., Santana-Casiano, M.J., Kortzinger, A., 554 2000. Alkalinity determination by potentiometry: Intercalibration using three different 555 methods. Ciencias Marinas 26, 23-37

556 Navarro, G., Ruiz, J., Huertas, I.E., Garcia, C.M., Criado-Aldeanueva, F., Echevarria, 557 F., 2006. Basin-scale structures governing the position of the deep fluorescence 558 maximum in the Gulf of Cadiz. Deep-Sea Research Part II-Topical Studies in 559 Oceanography 53, 1261-1281

560 Péliz, A., Marchesiello, P., Santos, A.M.P., Dubert, J., Teles-Machado, A., Marta561 Almeida, M., Le Cann, B., 2009. Surface circulation in the Gulf of Cadiz: 2. Inflow562 outflow coupling and the Gulf of Cadiz slope current. Journal of Geophysical Research563 Oceans 114

564 Pérez, F.F., Álvarez, M., Ríos, A.F., 2002. Improvements on the back-calculation 565 technique for estimating anthropogenic $\mathrm{CO}_{2}$. Deep-Sea Research Part I-Oceanographic 566 Research Papers 49, 859-875 
567 Pérez, F.F., Mintrop, L., Llinas, O., González-Davila, M., Castro, C.G., Alvarez, M.,

568 Kortzinger, A., Santana-Casiano, M., Rueda, M.J., Ríos, A.F., 2001. Mixing analysis of 569 nutrients, oxygen and inorganic carbon in the Canary Islands region. Journal of Marine 570 Systems 28, 183-201

571 Pollard, R.T., Griffiths, M.J., Cunningham, S.A., Read, J.F., Perez, F.F., Rios, A.F., 572 1996. Vivaldi 1991-A study of the formation, circulation and ventilation of Eastern

573 North Atlantic Central Water. Progress in Oceanography 37, 167-192

574 Poole, R., Tomczak, M., 1999. Optimum multiparameter analysis of the water mass 575 structure in the Atlantic Ocean thermocline. Deep-Sea Research Part I-Oceanographic 576 Research Papers 46, 1895-1921

577 Prieto, L., Navarro, G., Rodriguez-Galvez, S., Huertas, I.E., Naranjo, J.M., Ruiz, J., 578 2009. Oceanographic and meteorological forcing of the pelagic ecosystem on the Gulf 579 of Cadiz shelf (SW Iberian Peninsula). Continental Shelf Research 29, 2122-2137

580 Rhein, M., Hinrichsen, H.H., 1993. Modification of Mediterranean Water in the Gulf od 581 Cadiz, studied with hidrographic, nutrient and chlorofluoromethane data. Deep-Sea 582 Research Part I-Oceanographic Research Papers 40, 267-291

583 Ribas-Ribas, M., Gómez-Parra, A., Forja, J.M., 2011. Air-sea $\mathrm{CO}_{2}$ fluxes in the north584 eastern shelf of the Gulf of Cádiz (southwest Iberian Peninsula). Marine Chemistry 123, $585 \quad 56-66$

586 Ríos, A.F., Fraga, F., Pérez, F.F., 1989. Estimation of coefficients for the calculation of 587 "NO", "PO" and "CO", starting from the elemental composition of natural 588 phytoplankton*. Scientia Marina 53, 779-784

589 Ríos, A.F., Pérez, F.F., Fraga, F., 1992. Water masses in the upper and middle North590 Atlantic Ocean East of the Azores. Deep-Sea Research Part I-Oceanographic Research 591 Papers 39, 645-658

592 Ríos, A.F., Pérez, F.F., Fraga, F., 2001. Long-term (1977-1997) measurements of 593 carbon dioxide in the Eastern North Atlantic: evaluation of anthropogenic input. Deep594 Sea Research Part II-Topical Studies in Oceanography 48, 2227-2239

595 Sabine, C.L., Feely, R.A., Gruber, N., Key, R.M., Lee, K., Bullister, J.L., Wanninkhof, 596 R., Wong, C.S., Wallace, D.W.R., Tilbrook, B., Millero, F.J., Peng, T.H., Kozyr, A., 597 Ono, T., Rios, A.F., 2004. The oceanic sink for anthropogenic $\mathrm{CO}_{2}$. Science 305, 367$598 \quad 371$ 
599 Santana-Casiano, J.M., González-Davila, M., Laglera, L.M., 2002. The carbon dioxide

600 system in the Strait of Gibraltar. Deep-Sea Research Part II-Topical Studies in 601 Oceanography 49, 4145-4161

602 Sarmiento, J.L., Gruber, N., 2002. Sinks for anthropogenic carbon. Physics Today 55, $603 \quad 30-36$

604 Schneider, A., Tanhua, T., Körtzinger, A., Wallace, D.W.R., 2010. High anthropogenic 605 carbon content in the eastern Mediterranean. Journal of Geophysical Research-Oceans $606 \quad 115,11$

607 Serra, N., Ambar, I., 2002. Eddy generation in the Mediterranean undercurrent. Deep608 Sea Research Part II-Topical Studies in Oceanography 49, 4225-4243

609 Takahashi, T., 2009. Climatological mean and decadal change in surface ocean $\mathrm{pCO}_{2}$, 610 and net sea-air $\mathrm{CO}_{2}$ flux over the global oceans. Deep-Sea Research Part II-Topical 611 Studies in Oceanography 56, 554-577

612 Tanhua, T., Jones, E.P., Jeansson, E., Jutterstrom, S., Smethie, W.M., Wallace, D.W.R., 613 Anderson, L.G., 2009. Ventilation of the Arctic Ocean: Mean ages and inventories of 614 anthropogenic $\mathrm{CO}_{2}$ and CFC-11. Journal of Geophysical Research-Oceans 114

615 Touratier, F., Azouzi, L., Goyet, C., 2007. CFC-11, Delta C-14 and H-3 tracers as a 616 means to assess anthropogenic $\mathrm{CO}_{2}$ concentrations in the ocean. Tellus Series B617 Chemical and Physical Meteorology 59, 318-325

618 Touratier, F., Goyet, C., 2004a. Definition, properties, and Atlantic Ocean distribution 619 of the new tracer TrOCA. Journal of Marine Systems 46, 169-179

620 Touratier, F., Goyet, C., 2004b. Applying the new TrOCA approach to assess the 621 distribution of anthropogenic $\mathrm{CO}_{2}$ in the Atlantic Ocean. Journal of Marine Systems 46, 622 181-197

623 van Aken, H.M., 2000. The hydrography of the mid-latitude northeast Atlantic Ocean I:

624 The deep water masses. Deep-Sea Research Part I-Oceanographic Research Papers 47, $625 \quad 757-788$

626 Vázquez-Rodríguez, M., Padín, X.A., Ríos, A.F., Bellerby, R.G.J., Pérez, F.F., 2009a. 627 An upgraded carbon-based method to estimate the anthropogenic fraction of dissolved $628 \mathrm{CO}_{2}$ in the Atlantic Ocean. Biogeosciences Discussions 6, 4527-4571

629 Vázquez-Rodríguez, M., Touratier, F., Lo Monaco, C., Waugh, D.W., Padín, X.A., 630 Bellerby, R.G.J., Goyet, C., Metzl, N., Ríos, A.F., Pérez, F.F., 2009b. Anthropogenic 631 carbon distributions in the Atlantic Ocean: data-based estimates from the Arctic to the 632 Antarctic. Biogeosciences 6, 439-451 
633 Winkler, L.W., 1888. Die Bestimmung des im Wasser gelösten Sauerstoffes. Berichte

634 der deutschen chemischen Gesellschaft 21, 2843-2854

635

636

637

638

639

640 Fig. 1 Map of the location of the Gulf of Cadiz and the Strait of Gibraltar and sampling 641 grid during the $\mathrm{P}_{3} \mathrm{~A}_{2}$ cruise.

642

643 Fig. $2 \theta / \mathrm{S}$ diagram of the study area from 100 dbar depth to the bottom: a) CTD data.

644 Red stars represent the water types (WT) for the different water bodies (NACW,

645 NADW and MOW) used for the eOMP analysis; b) $\mathrm{A}_{\mathrm{T}}\left(\mu \mathrm{mol} \mathrm{kg}{ }^{-1}\right)$; c) AOU ( $\mu \mathrm{mol} \mathrm{kg}$

$\left.64{ }^{1}\right)$; d) $C_{T}\left(\mu \mathrm{mol} \mathrm{kg}^{-1}\right)$. Contour lines represent density anomaly expressed in $\mathrm{kg} \mathrm{m}^{-3}$.

647

648 Fig. 3 Vertical distributions of a N-S transect from 100 dbar to the bottom: a) Map of 649 the selected stations; b) Salinity; c)Potential temperature $\left({ }^{\circ} \mathrm{C}\right)$, d) Total Alkalinity $\left(\mathrm{A}_{\mathrm{T}}\right)$ 650 in $\mu \mathrm{mol} \mathrm{kg}{ }^{-1}$, e) Total Inorganic Carbon $\left(C_{\mathrm{T}}\right)$ in $\mu \mathrm{mol} \mathrm{kg}{ }^{-1}$ and e) Apparent Oxygen 651 Utilization (AOU) in $\mu \mathrm{mol} \mathrm{kg}{ }^{-1}$.

652

653 Fig. 4 Vertical distributions of an E-W transect from 100 dbar to the bottom: a) Map of 654 the selected stations; b) Salinity; c)Potential temperature $\left({ }^{\circ} \mathrm{C}\right)$, d) Total Alkalinity $\left(\mathrm{A}_{\mathrm{T}}\right)$ 655 in $\mu \mathrm{mol} \mathrm{kg}{ }^{-1}$, e) Total Inorganic Carbon $\left(C_{\mathrm{T}}\right)$ in $\mu \mathrm{mol} \mathrm{kg}{ }^{-1}$ and e) Apparent Oxygen

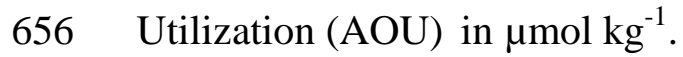

657

658 Fig. 5 Vertical distributions of a N-S transect from 100 dbar to the bottom: a-c) 659 Estimates of $\mathrm{C}_{\mathrm{ANT}}\left(\mu \mathrm{mol} \mathrm{kg}{ }^{-1}\right)$ from the $\varphi \mathrm{C}_{\mathrm{T}}{ }^{\circ}, \Delta \mathrm{C}^{*}$ and $\mathrm{TrOCA}_{2007}$ methods respectively; $660 \mathrm{~d}-\mathrm{f}$ ) percentage of NACW, NADW and MOW obtained by the eOMP analysis.

661

662 Fig. 6 Vertical distributions of an E-W transect from 100 dbar to the bottom: a-c)

663 Estimates of $\mathrm{C}_{\mathrm{ANT}}\left(\mu \mathrm{mol} \mathrm{kg}{ }^{-1}\right)$ from the $\varphi \mathrm{C}_{\mathrm{T}}^{\mathrm{o}}, \Delta \mathrm{C}^{*}$ and $\mathrm{TrOCA}_{2007}$ methods respectively; 664 d-f) percentage of NACW, NADW and MOW obtained by the eOMP analysis.

665

666 
Table 1. Biogeochemical characteristics of the water types selected as end-members in the eOMP analysis.

\begin{tabular}{|c|c|c|c|c|}
\cline { 2 - 5 } \multicolumn{1}{c|}{} & \multicolumn{2}{c|}{ NACW } & NADW & MOW \\
\cline { 2 - 5 } \multicolumn{1}{c|}{} & WT1 & WT2 & WT3 & WT4 \\
\hline $\mathbf{\Theta}\left({ }^{\circ} \mathrm{C}\right)$ & 17.3 & 11.3 & 2.4 & 13.1 \\
\hline $\mathbf{S}$ & 36.50 & 35.55 & 34.93 & 38.50 \\
\hline $\mathbf{O}_{\mathbf{2}}(\mu \mathrm{mol} \mathrm{kg}$ & & & 167 \\
\hline $\mathbf{S i}\left(\mu \mathrm{mol} \mathrm{kg}{ }^{-1}\right)$ & 217 & 179 & 235 & 9.9 \\
\hline $\mathbf{N O}_{\mathbf{3}}\left(\mu \mathrm{mol} \mathrm{kg}{ }^{-1}\right)$ & 2.05 & 15.56 & 20.55 & 10.81 \\
\hline $\mathbf{P O}_{\mathbf{4}}\left(\mu \mathrm{mol} \mathrm{kg}{ }^{-1}\right)$ & 0.16 & 1.14 & 1.39 & 1.20 \\
\hline $\mathbf{A}_{\mathbf{T}}{ }^{\mathbf{o}}\left(\mu \mathrm{mol} \mathrm{kg}{ }^{-1}\right)$ & 2362 & 2327 & 2300 & 2581 \\
\hline$\Delta \mathbf{C}_{\mathbf{d i s}}\left(\mu \mathrm{mol} \mathrm{kg}{ }^{-1}\right)$ & -17 & -6 & -8 & 0 \\
\hline
\end{tabular}


Table 2. Specific $\mathrm{C}_{\mathrm{ANT}}$ inventories in the area and the specific Mediterranean contribution (number of stations used=31, surface area=14,082 $\mathrm{Km}^{2}$ ).

\begin{tabular}{ccc}
\hline Method & $\begin{array}{c}\text { Specific Inventory } \\
\left(\text { mol } ~^{-2}\right)\end{array}$ & $\begin{array}{c}\text { Contribution of MOW to the } \\
\text { specific inventory (\%) }\end{array}$ \\
\hline$\varphi \mathrm{C}_{\mathrm{T}}^{\mathrm{o}}$ & $33.5 \pm 3.2$ & 8 \\
$\Delta \mathrm{C}^{*}$ & $34.2 \pm 3.2$ & 11 \\
$\mathrm{TrOCA}_{2007}$ & $33.7 \pm 3.0$ & 12 \\
$\operatorname{TrOCA}_{2004}$ & $38 \pm 3.1$ & \\
\hline
\end{tabular}




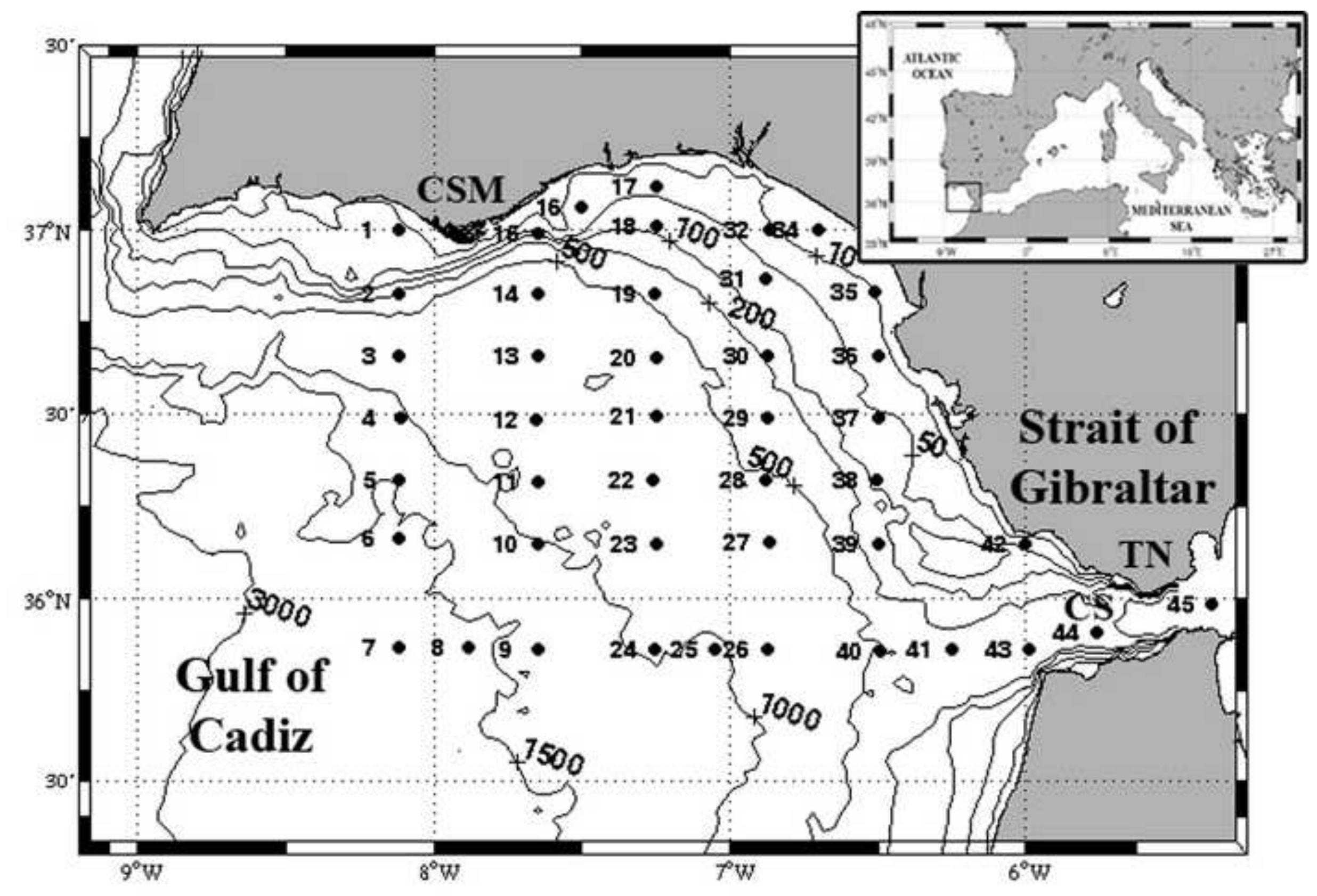


Click here to download high resolution image
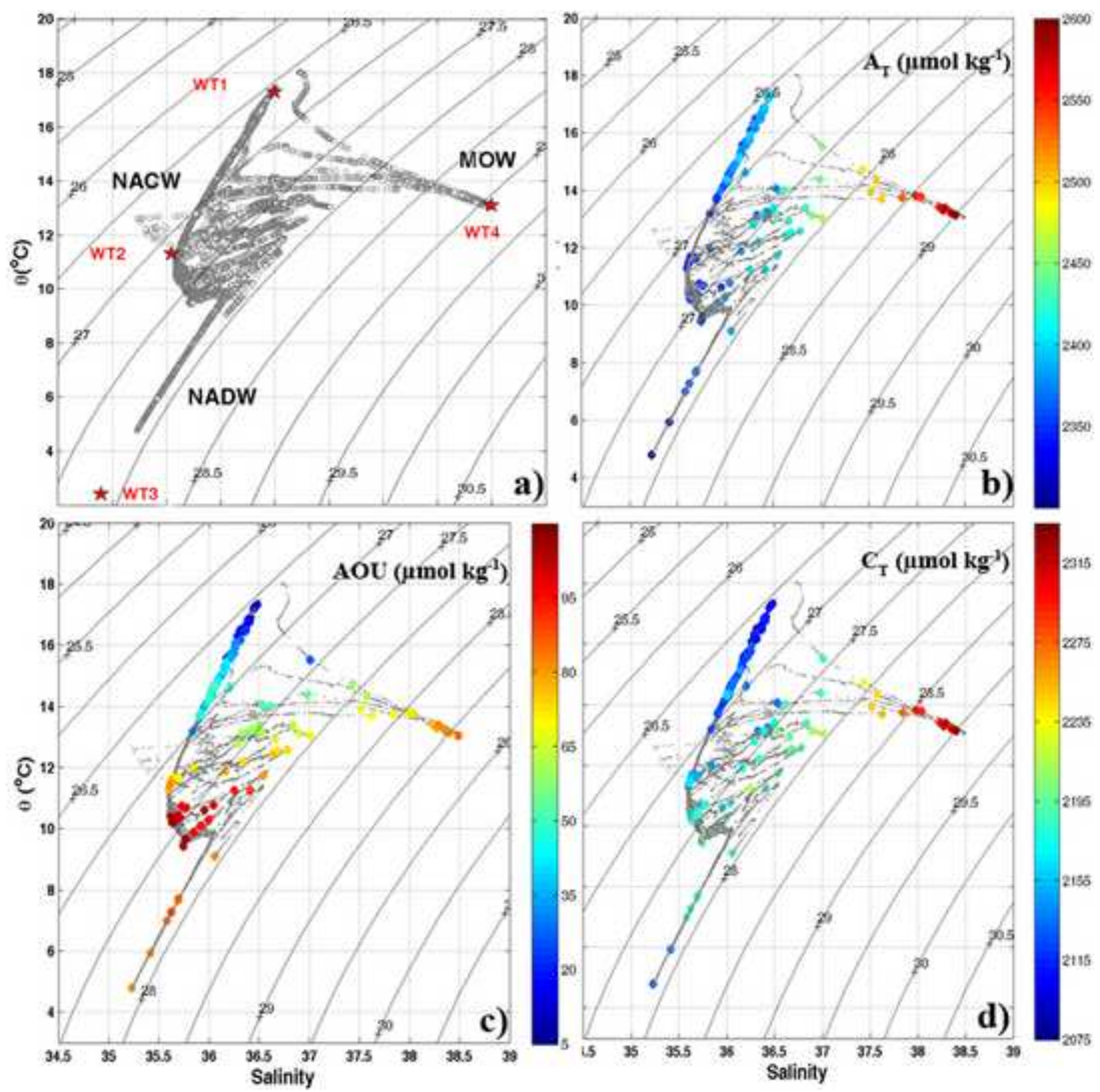
Click here to download high resolution image
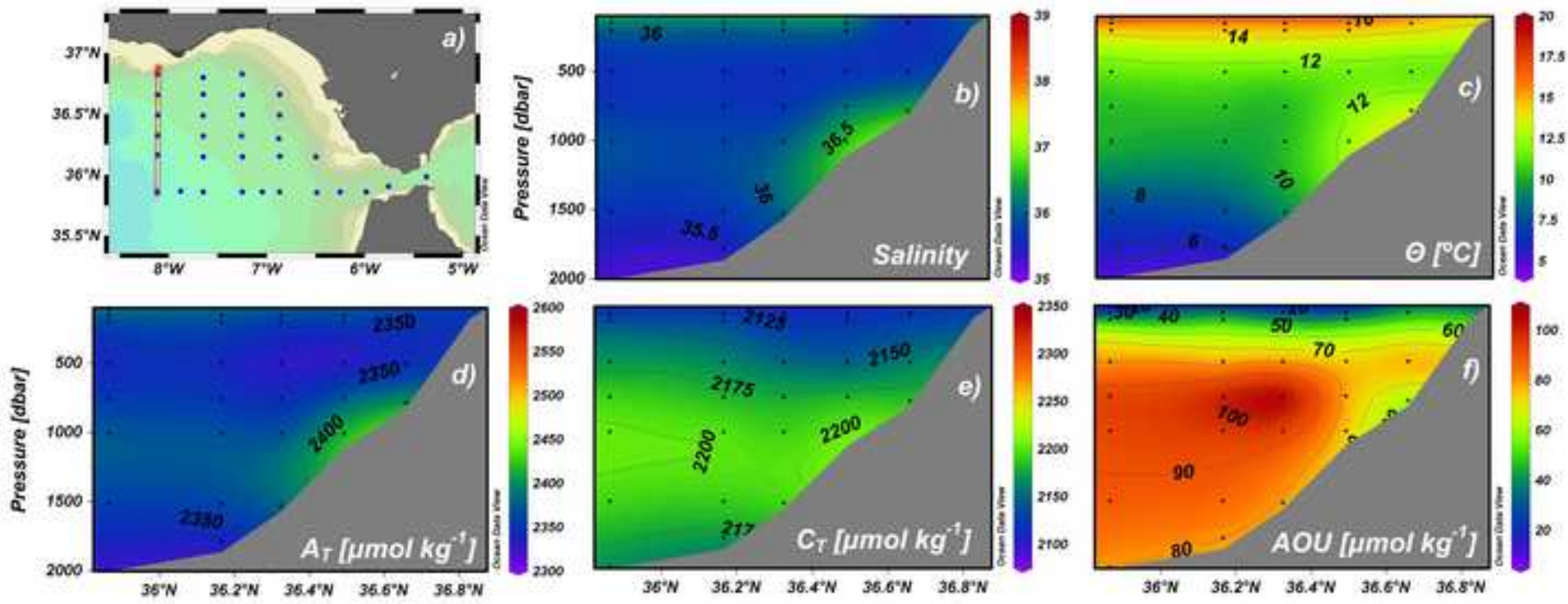

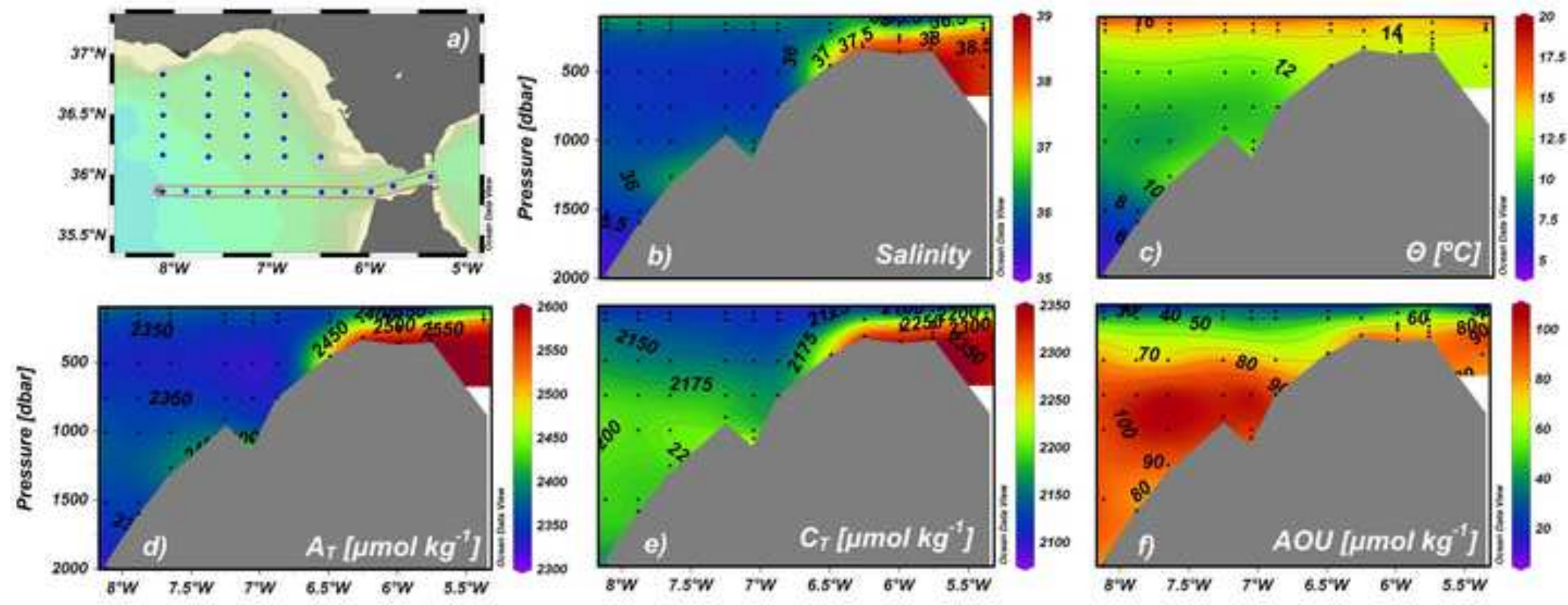

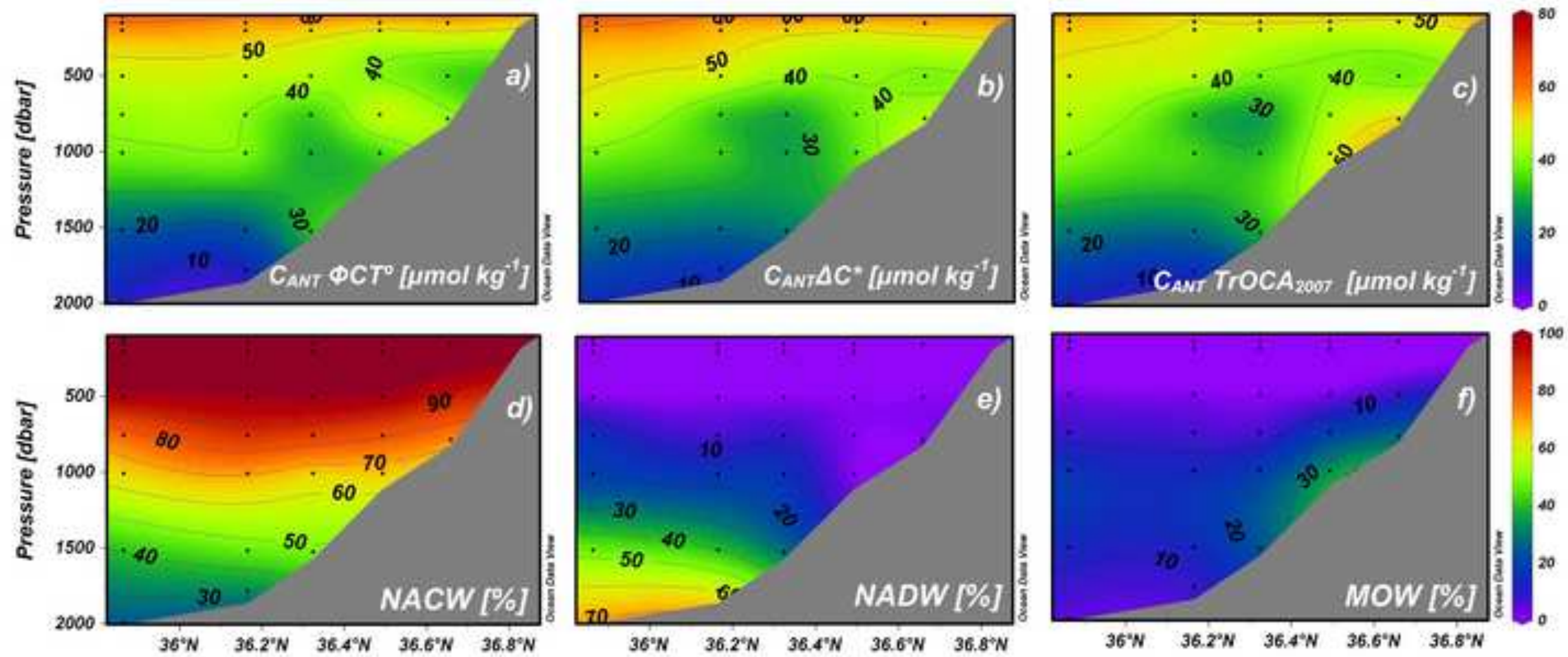
Click here to download high resolution image
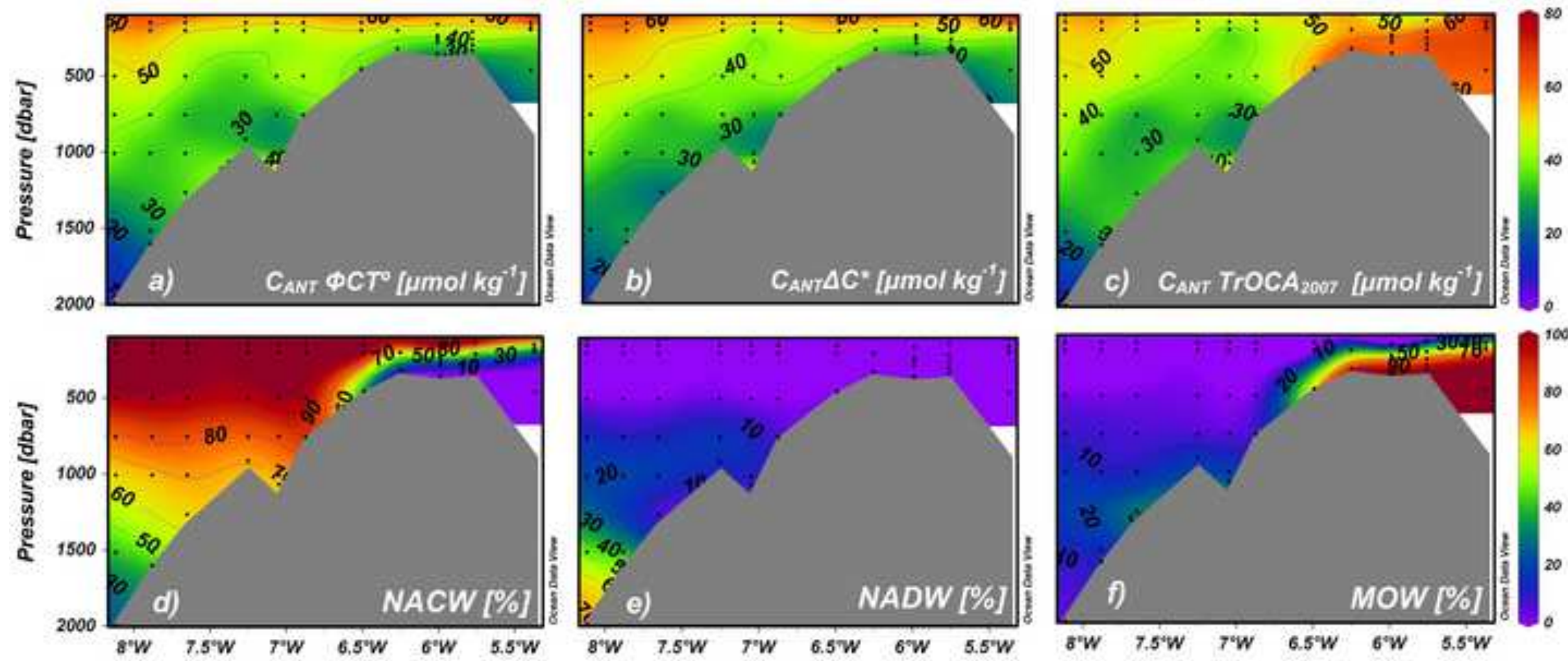